\title{
Predicting Potential Rastrelliger kanagurta Fish Habitat using MODIS Satellite Data and GIS Modeling: A Case Study of Exclusive Economic Zone, Malaysia \\ (Peramalan Potensi Habitat Ikan Rastrelliger kanagurta menggunakan Data Satelit MODIS dan Pemodelan GIS: Kajian Kes di Zon Ekonomi Eksklusif, Malaysia)
}

\author{
SHAARI, N.R. \& MUSTAPHA, M.A.*
}

\begin{abstract}
Remote sensing and GIS are robust tools in detection of fishing grounds which is important in providing fish sustainability for human being. This recent tool allows fishing grounds detection at minimal cost and optimizes effort. The objectives of this study were to investigate the relationship between $\mathrm{R}$. kanagurta fishing grounds with environmental factors and to determine its potential fishing grounds. MODIS derived satellite data of Chl-a and sea surface temperature (SST) and fisheries catch data of 2008 and 2009 were analyzed using suitability index (SI) and generalized additive model (GAM) in the Exclusive Economic Zone (EEZ) off the East Coast of Peninsular Malaysia. Distribution of R. kanagurta was associated with preferred range of 0.20 to $0.30 \mathrm{mg} / \mathrm{m}^{3}$ for Chl-a and 29 to $30^{\circ} \mathrm{C}$ for SST. GAM indicated that these parameters influenced fish distribution $(\mathrm{p}<0.001)$. Potential fishing ground maps derived from the SI and GAM model indicated accuracy at $75 \%$ with kappa of 0.7 and accuracy at $87.6 \%$ with kappa of 0.8 , respectively. This study indicated the capability of GAM as an exploratory tool to map the potential fishing grounds of R. kanagurta in the EEZ waters.
\end{abstract}

Keywords: Fisheries spatial prediction; generalized additive model; MODIS; suitability index model

\section{ABSTRAK}

Penderiaan jauh dan GIS merupakan pendekatan yang digunakan untk mengesan kawasan tangkapan ikan yang sangat penting dalam memastikan kelangsungan ikan untuk keperluan manusia. Ia membantu dalam penentuan kawasan tangkapan ikan dengan kos yang minimum dan usaha yang optimum. Objektif dalam kajian ini adalah untuk mengkaji perhubungan antara kawasan tangkapan ikan R. kanagurta dengan faktor persekitaran dan menentukan kawasan potensi tangkapan ikan. Data satelit Klorofil-a dan suhu permukaan laut (SPL) yang diperoleh daripada MODIS dan juga datadata ikan bagi tahun 2008 dan 2009 dianalisis menggunakan indeks kesesuaian (SI) dan model aditif umum (GAM) di kawasan Zon Ekonomi Eksklusif (ZEE) pantai timur Semenanjung Malaysia. Keputusan kajian mendapati taburan ikan $\mathrm{R}$. kanagurta berasosiasi dengan julat kesesuaian antara 0.20 hingga $0.30 \mathrm{mg} / \mathrm{m}^{3}$ bagi Klorofil-a dan 29 hingga $30^{\circ} \mathrm{C}$ bagi SPL. GAM menunjukkan parameter ini mempengaruhi taburan ikan ( $<<0.001)$. Peta kawasan potensi tangkapan ikan yang diperoleh daripada Indeks Kesesuaian (SI) dan model GAM menunjukkan ketepatan pada $75 \%$ masing-masing dengan Kappa 0.7 dan ketepatan 87.6\% dengan kappa 0.8. Kajian ini menunjukkan kebolehan GAM sebagai kaedah dalam penentuan kawasan potensi tangkapan ikan $\mathrm{R}$. kanagurta di perairan ZEE.

Kata kunci: Model aditif umum; model indeks kesuaian; MODIS; ramalan reruang perikanan

\section{INTRODUCTION}

The South China Sea (SCS) is the largest marginal sea in the Southeast Asia and forms part of the Pacific Ocean with an area about $3,500,000$ square $\mathrm{km}(1,400,000 \mathrm{sq} \mathrm{mi})$ starting from the equator to $23^{\circ} \mathrm{N}$ and from $99^{\circ} \mathrm{E}$ to $121^{\circ} \mathrm{E}$. The east coast of Peninsular Malaysia is located in the southwestern part of the SCS. The SCS harbors high diversity of fish and attracts the fishing activity in the Exclusive Economic Zone (EEZ). According to the Department of Fisheries Malaysia, the percentage of marine fish landings of eastern Peninsular Malaysia in 2015 was 384,778 tones accounting for $33.6 \%$ of the total landing in Peninsular Malaysia and Indian mackerel (Rastrelliger kanagurta) was among the major contributor. Fish will choose a more suitable habitat for feeding, shelter, reproduction and migration (Palacios et al. 2006). This fishing grounds regularly changes as it is influenced by the environmental factors. Habitat characteristics can drastically modify the abundance, distribution and availability of fish populations (Selvin \& Lipton 2012).

The study by Solanki et al. (2005) showed that physical processes in the upper ocean influenced biological processes and ultimately determined the distributions of pelagic fish. It has also been reported that environmental variability is largely responsible for the oscillations in the trend of important commercial coastal fisheries of the world, at intra as well as the inter-annual level and geographical regions (Checkley et al. 2000). The distribution of fish is influenced by various factors. Surface Chl-a which is considered as an index of biological productivity, is often 
related to fish production (Sachoemar et al. 2010). Sea surface temperature (SST) has also been used for decades by fisherman and researchers to determine fish habitat and fish sustainability.

The combination of SST and Chl-a are important to understand the relationship between physical characteristics with habitat suitability of $R$. kanagurta. The study by Zainuddin et al. (2004) indicated that combination of SST and Chl-a are often analyzed in determining potential fishing grounds. Several other studies have been carried out to understand the relationship between SST and Chl-a (Fox et al. 2005; Zainuddin et al. 2008, 2006).

The east coast of Peninsular Malaysia is highly influenced by the monsoon. This variability has been reported to influence distribution of Chl-a and SST (Shaari \& Mustapha 2017). Meanwhile, river outflow and precipitation have also been described as factors influencing variability of Chl-a and SST (Nazmi et al. 2013). Therefore, understanding effects of this variability on fish distribution is important. Integration of statistical modeling in determination of potential fish habitats can be applied to further understand the relationship between fish aggregation with variability of Chl-a and SST.

Many previous studies integrating statistical model were able to explain the relationship between physical parameters and fishing grounds. Wang et al. (2010) applied generalized additive model (GAM) and generalized linear model (GLM) to predict spatial pattern of potential albacore habitats and the results suggested that multispectrum satellite data can provide useful information to characterize and predict potential tuna habitats. A study on Yellow fin tuna in Northeast Indian Ocean using empirical cumulative distribution function (ECDF) and generalized additive model (GAM) showed a significant relationship between oceanographic factors and Yellow fin tuna catch rates (Rajapaksha et al. 2013). Habitat suitability index (HSI) model was developed to evaluate the variability of suitable habitat for neon flying squid (Ommastrephes bartamii) in the Northwest Pacific Ocean with environmental variables of SST, Chl-a, Sea surface height anomaly (SSHA) and sea surface salinity (SSS) and suggested that the La Nina event in 1998 tended to result in more favorable habitats for the O. bartamii (Yu et al. 2015).

There were several studies related to the use of remote sensing and GIS in determination of $R$. kanagurta distribution. The study approach by Razib and Mustapha (2013) applied density analysis to determine the distribution of $R$. kanagurta in the EEZ of east Peninsular Malaysia. Nurdin et al. (2012) was able to understand the aggregation of $R$. kanagurta in the Archipelagic waters of Spermonde Indonesia using suitability index while Nurdin et al. (2015) applied simple regression approach to determine the distribution of R. kanagurta using fish weight $(\mathrm{kg})$ data. Meanwhile, in this study, catch per unit effort (CPUE) which is an index that reflects fish abundance and accounts for changes in fishing activity was analyzed. This study also integrated the use of HSI and GAM which is a more robust statistical method.
Understanding the factors that influences habitat suitability is important for fisheries sustainability. Potential fishing grounds can be determined by statistical approaches and satellite data as it is capable in observing the vast area of ocean in real time. Thus, the objectives of this study were to investigate the relationship between $R$. kanagurta fishing grounds with environmental factors and to determine its potential fishing grounds using Suitability Index (SI) and GAM.

\section{MATERIALS AND METHODS}

This research study included analysis of fisheries data, image processing, modeling and mapping of fish potential habitats (Figure 1).

\section{STUDY AREA}

The study area extends between $1^{\circ}$ and $8^{\circ} \mathrm{N}$ latitude and $102^{\circ}$ to $106^{\circ} \mathrm{E}$ longitude covering the EEZ off east coast of Peninsular Malaysia (Figure 2). The EEZ is part of the SCS and is influenced by the East Asian monsoon system (Lau et al. 1998). The monsoon winds play a great role in the seasonal monsoon that occur annually in this area which includes the Southwest monsoon (May to September), Northeast monsoon (November to Mac) and the transition monsoon (April and October) (Maged 2009).

\section{FISHERIES DATA}

Fisheries data of $R$. kanagurta was provided by the Marine Fishery Resources Development and Management Department (MFRDMD). Catch was conducted using purse seine and the fish catch data consisted of fishing date, position, net size and catch weight $(\mathrm{kg})$. These data were then used to calculate catch per unit effort (CPUE) using the following formula:

$$
\mathrm{CPUE}=\mathrm{kg} / \mathrm{m}^{3}
$$

where $\mathrm{kg}$ is the total catch of fish; and $\mathrm{m}^{3}$ is the volume of fish net. The volume of the fish net was calculated as shown:

$$
m^{3}=\pi r^{2} \frac{h}{3}
$$

where $\pi$ is $3.14 ; r$ is the radius of the fish net; and $h$ is the height of the fish net.

\section{SATELLITE DATA}

The satellite imagery data of south-western part of SCS were downloaded, processed and analyzed. Daily MODIS Level $1(1 \mathrm{~km})$ data of Chl-a and SST were derived from NASA GSFCs Distributed Active Archive Center (DAAC). The data were processed to Level 3 using SeaWiFS Data Analysis System (SeaDAS) 7.4 and Erdas IMAGINE 2011. The algorithm applied to obtain the Chl-a data was calculated from the O'Reilly band ratio OCx (O'Reilly et al. 1998). 


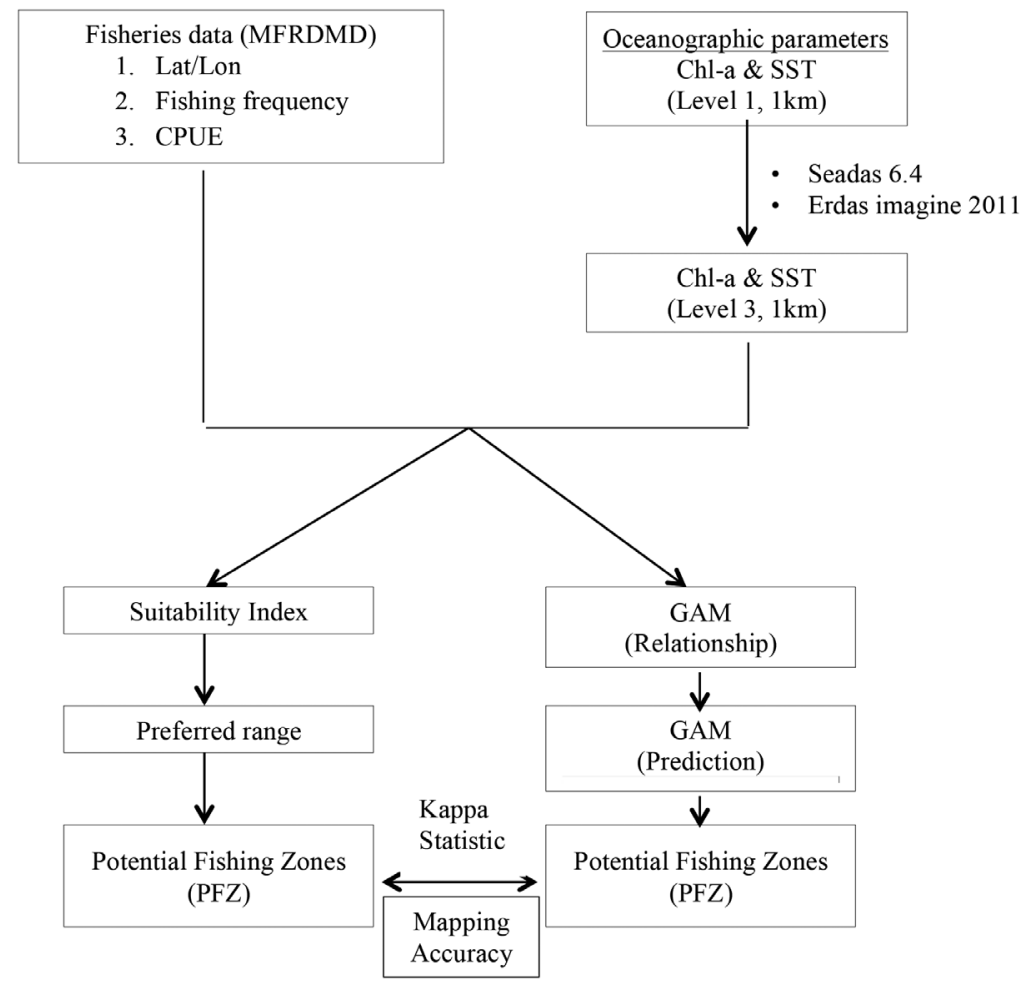

FIGURE 1. Overview of the research approach

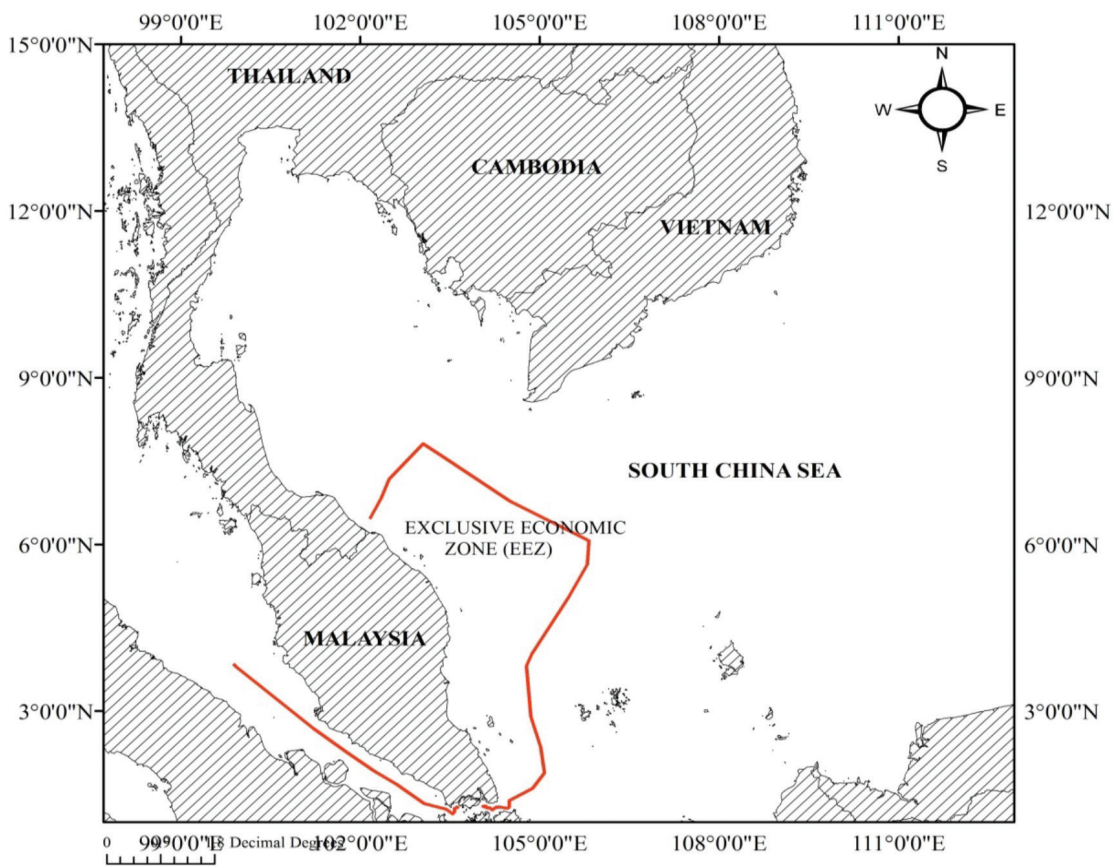

FIGURE 2. Map indicating location of the Exclusive Economic Zone (EEZ) off east coast of Peninsular Malaysia in the South China Sea

Meanwhile, the SST continuity algorithm was based on a modified version of the nonlinear SST algorithm of Walton et al. (1998) and uses empirical coefficients derived by regression of collocated in situ and satellite observations.
The data were processed and subset to the study area at geographical extent of $1^{\circ}$ to $8^{\circ} \mathrm{N}$ latitude and $102^{\circ}$ to $106^{\circ}$ E longitude and projected to cylindrical projection using ArcGIS. 


\section{SUITABILITY INDEX MODEL}

Fish catch frequency was analysed to determine the preferred range of the pelagic fish by relating the availability of fish catch data with the satellite images. Fishing effort is often considered to be an index of fish availability or fishing occurrence (Andrade \& Garcia 1999). This was used to derive suitability indexes. Habitat suitability index (HSI) models are widely used as a tool in fisheries management, ecological impact assessments and ecological restoration studies (Maddock 1999). The HSI models usually describe relations between fish abundance and ecological variables and estimate the level of habitat suitability. HSI objectively assess the range of environmental condition that fully, marginally or do not meet the requirements of a species (Wakeley 1988). Output produced from HSI modeling can predict the spatio-temporal variation of fish habitat conditions and can be used in combination with GIS to provide maps and information upon which managers can make informed decisions in fisheries management (Terrel 1984). Suitability index were derived using the following formula:

$$
\mathrm{SI}=\frac{\mathrm{Y}_{\mathrm{fit}}-\min \mathrm{Y}_{\mathrm{fit}}}{\max \mathrm{Y}_{\mathrm{fit}}-\min \mathrm{Y}_{\mathrm{fit}}}
$$

where $\mathrm{Y}_{\mathrm{fit}}$ is the predicted value of frequency (CPUE); and $\min \mathrm{Y}_{\text {fit }}$ and max $\mathrm{Y}_{\text {fit }}$ are, respectively, the minimum and maximum frequency (CPUE). The suitability index determined the level of scores of the preferred ranges for the pelagic fish. The satellite images were reclassified using these relevant scores to derive map of potential fishing area.

\section{GENERALIZED ADDITIVE MODEL}

GAM is a non-parametric generalization of multiple linear regressions, which is less restrictive in assumption of the underlying statistical data distribution (Hastie \& Tibshirani 1990). GAM consist of additive functions and smooth component that uses a link function to establish a relationship between the mean of the response variable and smoothed function of the explanatory variables (s). The strength of GAMs is their ability to deal with non-linear and non-monotonic relationship between the response and the set of explanatory variables. In GAMs, the data used determines the nature of the relationship between the response and the set of explanatory variables rather than assuming some form of parametric relationship (Yee \& Mitchell 1991). GAM enables determination of the relationship between CPUE and environmental variables. The environmental variables were included in the analysis using GAM equation as shown (Hastie \& Tibshirani 1990):

$$
\mathrm{y}=\mathrm{a}+s(\mathrm{SST})+s(\mathrm{SSC})+\mathrm{e}
$$

where y is CPUE; $a$ is constant; $s$ (.) is a spline smoothing function of the variables (SST and SSC); and e is a random error term.

\section{ACCURACY ASSESSMENT}

Kappa statistics was applied to compare the actual catch with the derived potential predicted catch. Kappa statistics characterized the degree of matching between reference data set and classification. The assessment determined accuracy level of the forecasting model used to generate the potential fishing ground maps (Vasconselos et al.2013). Kappa statistics formula is shown as follows:

$$
\mathrm{K}^{\wedge}=\frac{K^{\wedge}=N \sum_{i=1}^{r} x^{i i}-\sum_{i=1}^{r}\left(x_{i+} * x_{+i}\right)}{N^{2}-\sum_{i=1}^{r}\left(x_{i+} * x_{+i}\right)}
$$

where $K$ is the Kappa statistics; $N$ is total number of observations; $r$ is the number of rows in the matrix; $x_{i i}$ is the number of observations in row $i$ and column $i ; x_{i+}$ and $x_{+i}$ are the marginal number of row $i$ and column $i$, respectively.

\section{RESULTS AND DISCUSSION}

\section{SEASONAL VARIABILITY OF CPUE}

Variability of $R$. kanagurta catch was observed for all the year. High catch of $R$. kanagurta $\left(>150 \times 10^{-6}\left(\mathrm{~kg} / \mathrm{m}^{3}\right)\right)$ was observed in October and moderate catch $\left(>50 \times 10^{-6}(\mathrm{~kg} /\right.$ $\left.\mathrm{m}^{3}\right)$ ) in May, July and August. Catch lower than $50 \times 10^{-6}$ $\left(\mathrm{kg} / \mathrm{m}^{3}\right)$ was observed during the other months (Figure 3). The distribution of $R$. kanagurta from the suitability index was observed in the range of SST and Chl-a between 26.17 and $32.74^{\circ} \mathrm{C}$ and 0.12 to $0.92 \mathrm{mg} / \mathrm{m}^{3}$, respectively. Figure 3 shows the highest frequency of CPUE for SST and Chl-a were at $28.8-29.45^{\circ} \mathrm{C}$ and $0.2-0.3 \mathrm{mg} / \mathrm{m}^{3}$, respectively. Among the ten scores of SST and Chl-a classes, scores 1, 2 and 3 indicated high distribution of R. kanagurta with $47.8 \%$ of the total frequency (Figure 4 ).

The GAM model analysis also indicated high distribution of $R$. kanagurta related to Chl-a and SST in the range of $0.20-0.30 \mathrm{mg} / \mathrm{m}^{3}$ and $29-30^{\circ} \mathrm{C}$, respectively (Figure 5). GAM test indicated that SST and Chl-a had significant relationship with the $R$. kanagurta distribution at $p<0.001$ and $p<0.01$, respectively (Table 1 ). SST indicated stronger influence compared to Chl-a suggesting greater influence on the distribution of R. kanagurta. The significant relationship convergence of SST was obtained at the range of $29-30^{\circ} \mathrm{C}$ and $\mathrm{Chl}-\mathrm{a}$ at $0.2-0.3 \mathrm{mg} / \mathrm{m}^{3}$. The results of both approaches were consistence with the study of Mustapha et al. (2010) in the South China Sea, which recorded the highest fishing frequency of $R$. kanagurta within Chl-a range of $0.24-0.30 \mathrm{mg} / \mathrm{m}^{3}$ and SST range of $29.60^{\circ} \mathrm{C}-30.20^{\circ} \mathrm{C}$.

\section{ANALYSIS OF SUITABILITY INDEX MODEL}

The scores of SST and Chl-a derived from the SI model were classified in GIS to produce a simple prediction map of R. kanagurta (Figure 6(a)). The actual fish catch 


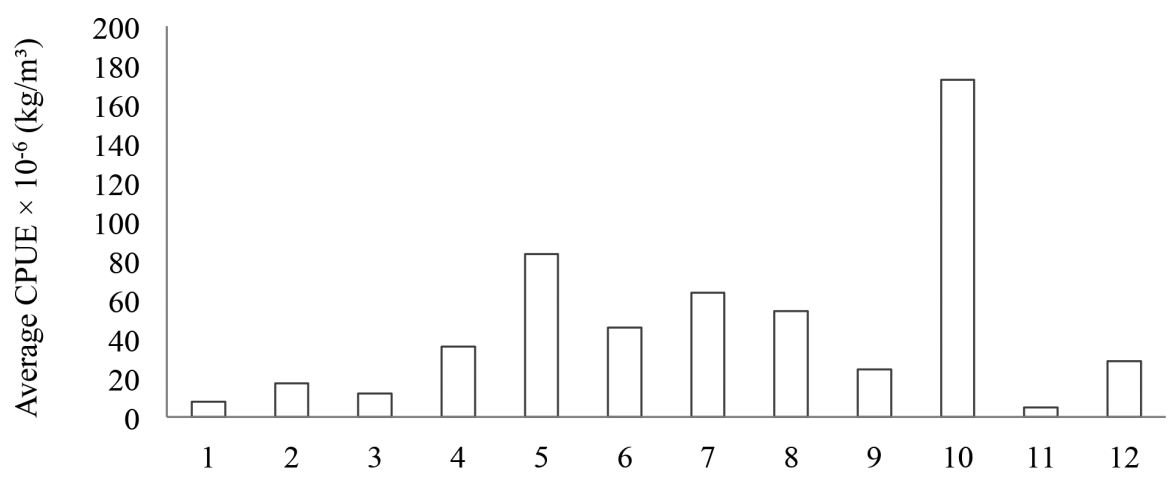

FIGURE 3. Average CPUE for R. kanagurta in 2008 and 2009 from January to December

(a)

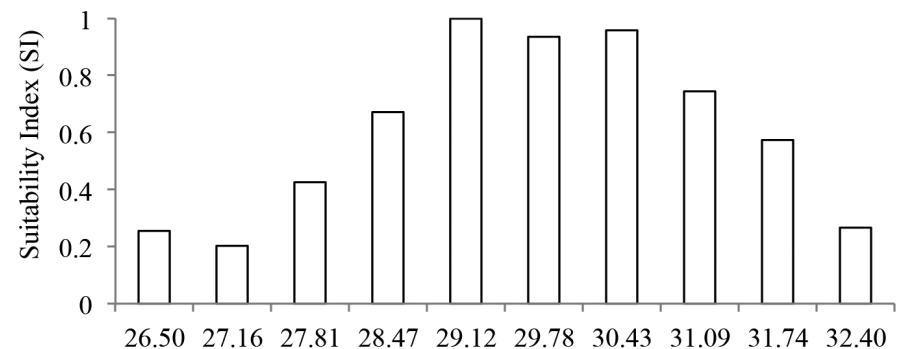

Sea Surface Temperature $\left({ }^{\circ} \mathrm{C}\right)$

(b)

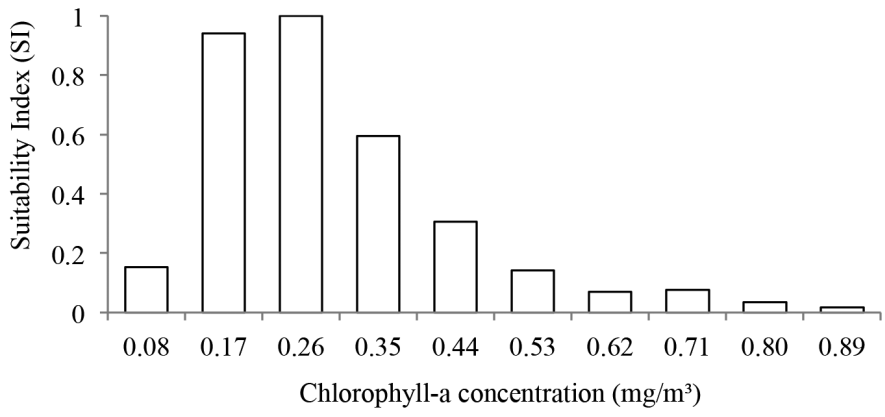

FIGURE 4. Suitability index analysis indicating the preferred range of (a) SST and (b) Chl-a

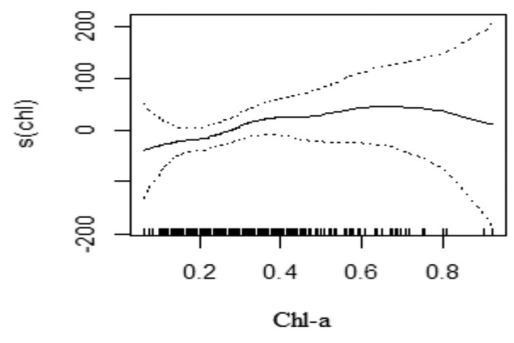

(a)

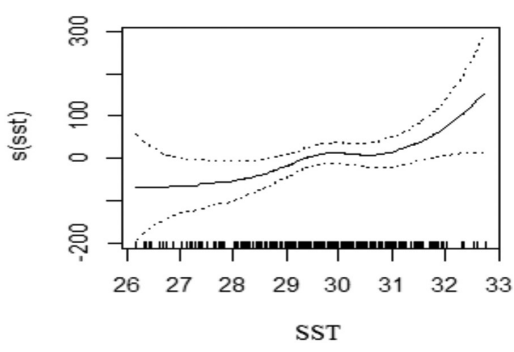

(b)

FIGURE 5. GAM analysis of $R$. kanagurta catch against (a) Chl-a and (b) SST

Dashed lines indicates $95 \%$ confidence intervals 
TABLE 1. Relationship of environmental variables of SST and Chl-a with $R$. kanagurta

\begin{tabular}{|c|c|c|c|c|c|}
\hline & Df & Sum Sq & Mean Sq & F value & $\operatorname{Pr}(>\mathrm{F})$ \\
\hline $\mathrm{s}(\mathrm{Chl}-\mathrm{a})$ & 1 & 185525 & 185525 & 4.8078 & $0.028915 *$ \\
\hline $\mathrm{s}(\mathrm{sst})$ & 1 & 386087 & 386087 & 10.0053 & $0.001682 * *$ \\
\hline Residuals & 394 & 15203824 & 38588 & & \\
\hline Significan & \multicolumn{3}{|c|}{0 ‘***’ 0.001 ‘**’ 0.01 ‘*’ 0.05 ‘' 0.1 “ ' 1} & & \\
\hline
\end{tabular}

was plotted on the map to indicate the actual fish catch value in the potential fishing zones. The reliability of the prediction indicated $75 \%$ of accuracy with Kappa statistics of 0.7. High potential areas of $R$. kanagurta were predicted scattered near the coast and offshore of the EEZ. On 16th February 2009 (Figure 6(a)), high potential fishing zones $\left(>185 \times 10^{-6}\left(\mathrm{~kg} / \mathrm{m}^{3}\right)\right)$ were obtained at the northern area of the EEZ. Near the coast predicted catches of $75-90 \times 10^{-6}$ $\left(\mathrm{kg} / \mathrm{m}^{3}\right)$ were observed and this was also indicated by the actual fish catch data which showed catches below $100 \times$ $10^{-6}\left(\mathrm{~kg} / \mathrm{m}^{3}\right)$. Meanwhile high distribution of $R$. kanagurta $\left(90-250 \times 10^{-6}\left(\mathrm{~kg} / \mathrm{m}^{3}\right)\right)$ was found scattered at the center and south area of EEZ on 17th April 2009. Predicted catches at $35-120 \times 10^{-6}\left(\mathrm{~kg} / \mathrm{m}^{3}\right)$ near the northern coast was also observed and this was consistent with actual catch of 50$150 \times 10^{-6}\left(\mathrm{~kg} / \mathrm{m}^{3}\right)$. On 26th June 2009, high distribution of $R$. kanagurta $\left(>120 \times 10^{-6}\left(\mathrm{~kg} / \mathrm{m}^{3}\right)\right)$ was observed near the coast of center and southern area of EEZ. This high distribution was also observed offshore at the northern area. Actual catch at $>101 \times 10^{-6}\left(\mathrm{~kg} / \mathrm{m}^{3}\right)$ was predicted in this area. As for 7 th October 2008 , high catches $\left(185 \times 10^{-6}\right.$ $\left.\left(\mathrm{kg} / \mathrm{m}^{3}\right)\right)$ was predicted at the center and southern areas. Actual catch data also indicated catches above $185 \times 10^{-6}$ $\left(\mathrm{kg} / \mathrm{m}^{3}\right)$ at the southern area. Apart from that predicted catches above $75 \times 10^{-6}\left(\mathrm{~kg} / \mathrm{m}^{3}\right)$ was also scattered in the EEZ areas. Actual catch data also indicated catches $>75 \times$ $10^{-6}\left(\mathrm{~kg} / \mathrm{m}^{3}\right)$ at locations near coast.

\section{ANALYSIS OF GENER ALIZED ADDITIVE MODEL}

Potential fishing ground of $R$. kanagurta mapped using GAM model indicated accuracy at $87.6 \%$ with Kappa of 0.8 (Figure 6(b)). On 13th January 2008, high potential area $\left(>200 \times 10^{-6}\left(\mathrm{~kg} / \mathrm{m}^{3}\right)\right)$ was obtained at the northern part of EEZ and $>100 \times 10^{-6}\left(\mathrm{~kg} / \mathrm{m}^{3}\right)$ was observed near the coast. In contrast, relatively low predicted catches $\left(10 \times 10^{-6}(\mathrm{~kg} /\right.$ $\left.\mathrm{m}^{3}\right)$ ) was obtained at offshore areas. High potential catch $\left(>200 \times 10^{-6}\left(\mathrm{~kg} / \mathrm{m}^{3}\right)\right)$ was obtained at the coast of northern, center and southern part of EEZ on 17th April 2009. The actual catch in the northern area showed value at more than $51-150 \times 10^{-6}\left(\mathrm{~kg} / \mathrm{m}^{3}\right)$. Meanwhile, low predicted catches $\left(10 \times 10^{-6}\left(\mathrm{~kg} / \mathrm{m}^{3}\right)\right)$ was observed at the center of the EEZ. On 6th June 2009, high distribution of R. kanagurta (>200 $\left.\times 10^{-6}\left(\mathrm{~kg} / \mathrm{m}^{3}\right)\right)$ was found scattered at the northern area and along the northern coast of EEZ. The actual catch at 101-150 $\times 10^{-6}\left(\mathrm{~kg} / \mathrm{m}^{3}\right)$ was observed in this area. Meanwhile, on 7th October 2008, high distribution of R. kanagurta was obtained at the northern and at the center of the EEZ. The actual catch $\left(101-150 \times 10^{-6}\left(\mathrm{~kg} / \mathrm{m}^{3}\right)\right)$ observed coincided with the predicted catch $\left(100 \times 10^{-6}\left(\mathrm{~kg} / \mathrm{m}^{3}\right)\right)$.

\section{SEASONAL DISTRIBUTION OF R. KANAGURTA}

In this study, distribution of R. kanagurta was observed at the northern waters and along the coast during Northeast monsoon. During this season, high precipitation and lower temperature provided a suitable environment for $R$. kanagurta. This was supported by the study of Saadon and Carmelengo (1994) that reported during Northeast monsoon, temperature and salinity recorded were lower. SST ranged between 28.5 and $30.5^{\circ} \mathrm{C}$ (Daryabor et al. 2014). Salinity and temperature are important layers in formation of water stratification. Water stratification creates barrier to nutrient mixing between layers influencing the primary production in the area. High concentration of Chl-a is observed near the coastal area during this monsoon. High concentration of Chl-a resulted from river discharge which carries nutrients from mainland and also as a result of several dynamic processes which occurs at the coastal area (Xian et al. 2012). Nutrient is fundamental for growth of phytoplankton (Chandran et al. 2009). As a result of stratification, availability of high Chl-a at the surface attracts presence of fish.

Intermonsoons also influenced the distribution of $R$. kanagurta. High distribution was observed near the coastal area during intermonsoon. The study by Akhir et al. (2014) indicated that current direction during both periods had similar direction as Northeast and Southwest monsoons. Referring to Figure 6(b), higher distribution was observed on 17th April 2009 as compared to 7th October 2008. This was influenced by wind pattern and current that occurred during this period. Wind pattern is much weaker during months of April and May. Current during April tends to move southward according to the influence of northeast monsoon circulation, but the intensity was lower compared to the circulation during monsoon (Akhir 2012). Large sea surface heating and weak sea surface wind during April resulted in the development of stratification. Thus, this also encourages a stable environment for fishes to feed and breed. Areas of relatively stable temperature and high Chl-a concentration may attract feeding pelagic species (Chandran et al. 2009).

During Southwest monsoon, temperature is slightly higher than Northeast due to the increased solar radiation and the advection of warm water from the southern region. The distribution of $R$. kanagurta was found near to the 
coastal area of Peninsular Malaysia (Figure 6(b)) with high distribution scattered in the northern area of the EEZ to the Gulf of Thailand. According to Akhir (2012), southwest monsoon system dominates the coastal area of Peninsular Malaysia. The current flows from the south, with the strongest current flowing at the western side into the Gulf of Thailand before joining another coastal current within the gulf which then flows towards the southern tip of Vietnam. The distribution of $R$. kanagurta along the coastal area of Peninsular Malaysia was explained by the study of Daryabor (2014) that stated strong Southwest monsoon wind in this region caused the existence of coastal upwelling along the east coast of Peninsular Malaysia. This southwesterly upwelling feature is enhanced by favorable wind during this monsoon. Usually, the deep water is brought to the surface and is rich in nutrient, thus coastal upwelling supports the growth of plankton. These in turn, provided food for fish.

At the end of southwest monsoon, the regulation of wind changes when approaching October. During intermonsoon of October, heavy rainfall and solar radiation due to overcast skies causes lower temperature (Saadon $\&$ Camerlengo 1994). Increased river discharge and lower temperature caused the distribution of $R$. kanagurta to
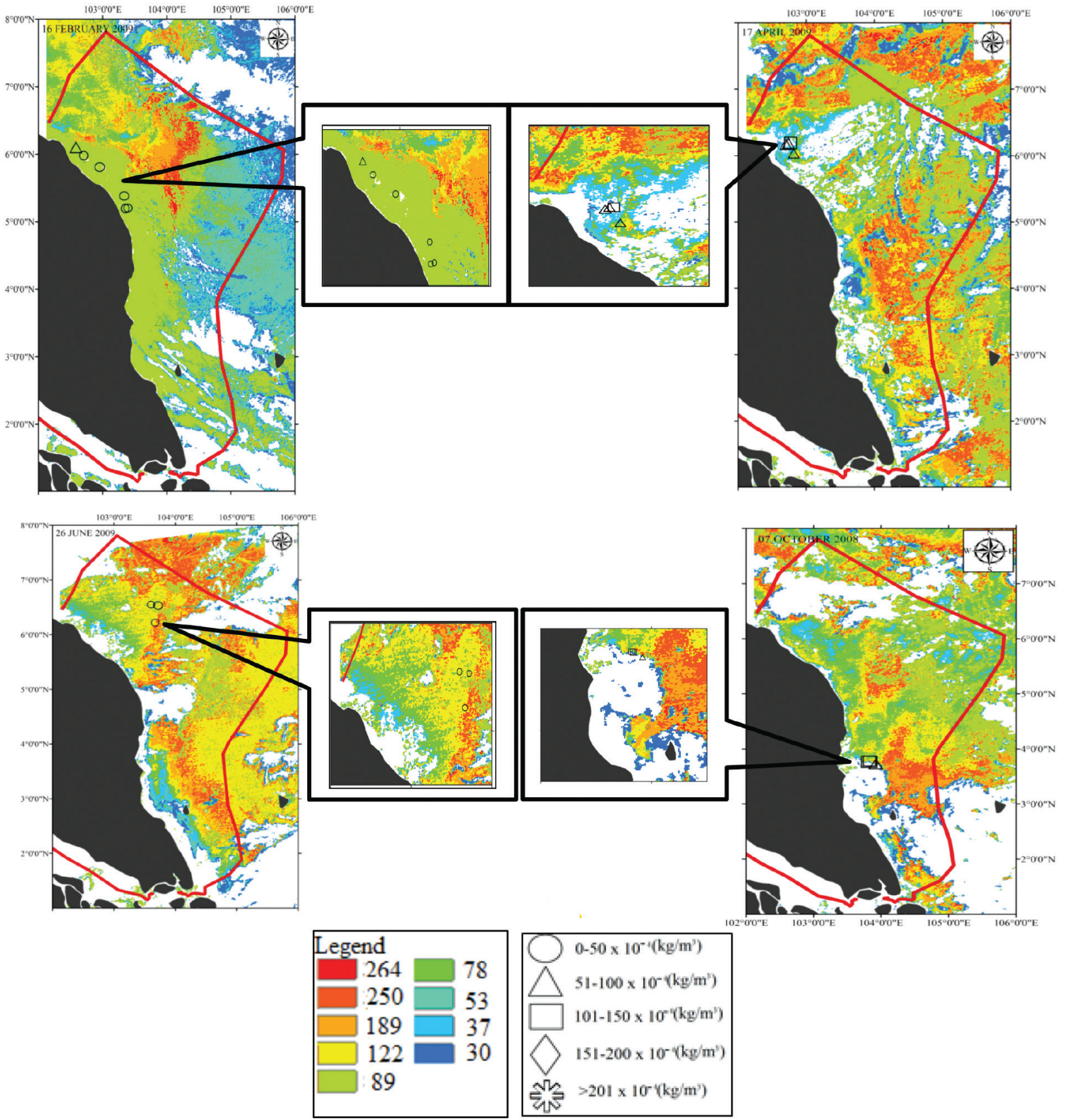

(a) 

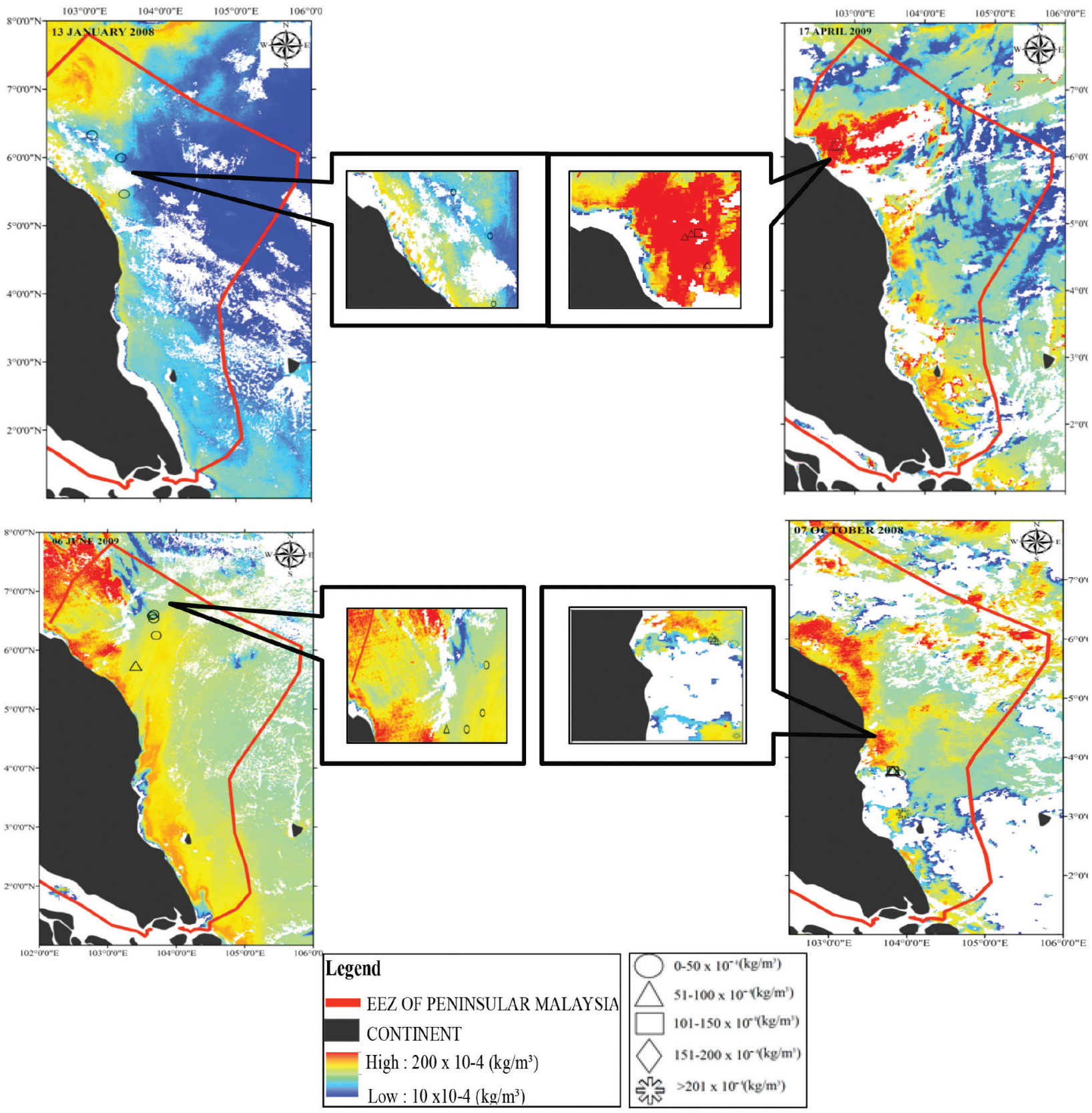

(b)

FIGURE 6. Potential fishing ground map of $R$. kanagurta (left and right panel) using (a) Suitability index and (b) GAM analysis in the SCS. Center panel indicated locations displaying predicted and actual catch

be observed scattered near the coast. River discharges have been reported to contribute to high nutrient. Thus, providing a potential fishing area for $R$. kanagurta near the coast.

RELATIONSHIP BETWEEN ENVIRONMENTAL VARIABLE AND PELAGIC FISH

It was observed that high catches of $R$. kanagurta was obtained during Intermonsoon and Southwest monsoon in the northern area of EEZ in comparison to the Northeast monsoon although higher Chl-a was found during this monsoon. This indicated that high Chl-a was not an indicator of high distribution of R. kanagurta. Study by Wang et al. (2010) found that high Chl-a concentration is less suitable for fish because it generates high water density that reduces oxygen supply in the water.

Chl-a is known as an important indicator relating to formation of area where small pelagic fish concentrate for foraging (Lanz et al. 2009). However, it has been suggested that SST has the greatest influence on fish distribution. Water temperature is an important factor in fish environment. It controls the activity levels of fish, influences fish to move to 
certain areas while avoiding others and influences feeding and reproductive activity. Previous studies have also stated SST as an indicator for aggregation and migration of fish (Santos 2000; Zainuddin 2011). SST obtained in this study had higher influence on fish distribution in comparison to Chl-a. However, the availability of Chl-a is important as food provider for survival of fish. Thus, relationships between these two parameters are very significant for fish productivity. Both models in this study indicated similar prediction in potential habitats according to monsoon. However GAM analysis gave higher prediction accuracy compared to suitability index model.

\section{CONCLUSION}

Suitability index model and GAM were found to be able to predict potential fishing grounds of $R$. kanagurta. High distribution of $R$. kanagurta was obtained between 0.20 and $0.30 \mathrm{mg} / \mathrm{m}^{3}$ for Chl-a and 29 to $30^{\circ} \mathrm{C}$ for SST and was influenced by the variability of physical characteristic of SCS. This study demonstrated that potential fishing zones of $R$. kanagurta can be mapped using suitability index model and GAM at $75 \%$ and $87.6 \%$ of accuracy with kappa at 0.7 and 0.8 , respectively. This study indicated the potential of MODIS satellite data in determination of R. kanagurta distribution. Its high temporal and spatial resolution enables observation of the dynamic oceanographic processes influencing fish habitats.

\section{ACKNOWLEDGEMENTS}

The authors would like to thank the Distributed Active Archive Center at the NASA Goddard Space Flight Centre for the MODIS data provided, SEAFDEC and Fisheries Department of Malaysia for the fisheries data. We are also grateful to the Faculty of Science and Technology, UKM for the research facilities and technical assistance provided. This work has been supported by the Universiti Kebangsaan (UKM) grant No. AP-2013-05.

\section{REFERENCES}

Akhir, M.F. 2012. Surface circulation and temperature distribution of Southern South China Sea from global ocean model (OCCAM). Sains Malaysiana 41(6): 701-714.

Akhir, M.F., Zakaria, N.Z. \& Tangang, F. 2014. Intermonsoon variation of physical characteristics and current circulation along the east coast of Peninsular Malaysia. International Journal of Oceanography 2014: 1-9.

Andrade, H.A. \& Garcia, C.A.E. 1999. Skipjack tuna fishery in relation to sea surface temperature off the southern Brazilian Coast. Fisheries Oceanography 8(4): 245-254.

Chandran, R.V., Jeyaram, A., Jayaraman, V., Manoj, S., Rajitha, K. \& Mukherjee, C.K. 2009. Prioritization of satellite derived potential fishery grounds: An analytical hierarchical approach-based model using spatial and non-spatial data. International Journal of Remote Sensing 30(17): 4479-4491.

Checkley, D.M., Dotson, R.C. \& Griffith, D.A. 2000. Continuous, underway sampling of eggs of Pacific sardine (Sardinops sagax) and northern anchovy (Engraulis mordax) in spring
1996 and 1997 off southern and central California. Deep Sea Research Part II 47: 1139-1155.

Daryabor, F., Tangang, F. \& Juneng, L. 2014. Simulation of southwest monsoon current circulation and temperature in the east coast of Peninsular Malaysia. Sains Malaysiana 43(3): 389-398.

Fox, M.F., Kester, D.R. \& Yoder, J.A. 2005. Spatial and temporal distributions of surface temperature and chlorophyll in the Gulf of Maine during 1998 using SeaWiFS and AVHRR imagery. Marine Chemistry 97: 104-123.

Hastie, T.J. \& Tibshirani, R.J. 1990. Generalized Additive Models. London: Chapman \& Hall.

Lanz, E., Manuel, N.M., Juana, L.M. \& Dworak, J.A. 2009. Small pelagic fish catches in the Gulf of California associated with sea surface temperature and chlorophyll. CalCOFI Report 50: 134-146.

Lau, K.M., Wu, H.T. \& Yang, S. 1998. Hydrologic processes associated with the first transition of the Asian Summer Monsoon: A pilot satellite study. Bulletin American Meteorological Society 79: 1871-1882.

Maddock, I. 1999. The importance of physical habitat assessment for evaluating river health. Freshwater Biology 41: 373-391.

Maged, M. 2009. Linear algorithm for salinity distribution modelling from MODIS data. Proceedings of Geoscience and Remote Sensing Symposium, Cape Town, South Africa.

Mustapha, A.M., Chan, Y.L. \& Lihan, T. 2010. Mapping of potential fishing grounds of Rastrelliger kanagurta (Cuvier, 1817) using satellite images. Proceedings of Map Asia \& ISG 2010, July 2010, Kuala Lumpur, Malaysia.

Nurdin, S., Lihan, T. \& Mustapha, A.M. 2012. Mapping of potential fishing grounds of Rastrelliger kanagurta (Cuvier, 1816) in the Archipelagic Waters of Spermonde Indonesia Using Satellite Images. Proceedings of Malaysia Geospatial Forum, March 2013, Melaka, Malaysia.

Nurdin, S., Mustapha, M.A., Lihan, T. \& Ghaffar, M.A. 2015. Determination of potential fishing grounds of Rastrelliger kanagurta using satellite remote sensing and GIS technique. Sains Malaysiana 44(2): 225-232.

O’Reilly, J.E., Maritorena, S., Mitchell, B.G., Siegel, D.A., Carder, K.L., Garver, S.A., Kahru, M. \& McClain, C.R. 1998. Ocean color chlorophyll algorithms for SeaWiFS. Journal of Geophysical Research 103: 24937-24953.

Palacios, D.M., Bograd, S .J., Foley, D.G. \& Scwing, F.B. 2006. Oceanographic characteristics of biological hot spots in the North Pacific: A remote sensing perspective. Deep-Sea Research Part II 53: 250-269.

Rajapaksha, J.K., Samarakoon, L. \& Gunathilaka, A.A.J.K. 2013. Environmental preferences of Yellowfin Tuna in the Northeast Indian Ocean: An application of satellite data to longline Catches. International Journal of Fisheries and Aquatic Sciences 2(4): 72-80.

Razib, N.A. \& Mustapha, M.A. 2013. Spatial distribution of Rastrelliger kanagurta (cuvier 1817) in the South China Sea exclusive economic zone (eez). UKM-FST Postgraduate Colloqium 2013, American Institute of Physics Conference Proceedings, July 2013, Bangi, Malaysia.

Saadon, M.N. \& Camerlengo, A. 1994. Interannual and seasonal variability of the mixed layer depth of the South China Sea. Paper Read at National Conference on Climate Change. pp. 141-151.

Sachoemar, S.I.T., Yanagi, N., Hendiarti, M., Sadly \& Meliani, F. 2010. Seasonal variability of sea surface chlorophyll-a and abundance of pelagic fish in Lampung Bay, Southern 
Coastal Area of Sumatra, Indonesia. Coastal Marine Science 34: 82-90.

Santos, A.M.P. 2000. Fisheries oceanography using satellite and airborne remote sensing methods: a review. Fisheries Research 49: 1-20.

Selvin, J. \& Lipton, A.P. 2012. Impact of environmental variables on pelagic fish landings: Special emphasis on Indian oil sardine off Tiruchendur coast, Gulf of Mannar. Journal of Oceanography and Marine Science 3(3): 56-67.

Shaari, F. \& Mustapha, M.A. 2017. Factors influencing the distribution of chl-a along coastal waters of East Peninsular Malaysia. Sains Malaysiana 46(8): 1191-1200.

Solanki, H.U., Dwivedi, R.M., Nayak, S.R., Naik, S.K., John, M.E. \& Somvanshi, V.S. 2005. Cover: Application of remotely sensed closely coupled biological and physical process for marine fishery resources exploration. International Journal of Remote Sensing 26(10): 2029-2034.

Nazmi, S.M., Mustapha, A.M. \& Lihan, T. 2013. Satellite derived measurements of coastal water chlorophyll-a variability. World Applied Sciences Journal 21(6): 879-887.

Terrel, J.W. 1984. Proceedings of a Workshop on Fish Habitat Suitability Index Models. US Fish and Wildlife Service Biological Report 85(6): 1-393.

Vasconcelos, R.P., Le Pape, O., Costa, M.J. \& Cabral, H.N. 2013. Predicting estuarine use patterns of juvenile fish with generalized linear models. Estuarine, Coastal and Shelf Science 120: 64-74.

Wakeley, J.S. 1988. A method to create simplified versions of existing Habitat Suitability Index (HSI) models. Environmental Management 1: 79-83.

Walton, C.C., Pichel, W.G., Sapper, J.F. \& May, D.A. 1998. The development and operational application of nonlinear algorithms for the measurement of sea surface temperatures with the NOAA polar-orbiting environmental satellites. Journal of Geophysical Research 103(C12): 27999-28012.

Wang, W., Zhou, C., Shao, Q. \& Mulla, D.J. 2010. Remote sensing of sea surface temperature and Chlorophyll- $a$ : Implications for squid fisheries in the north-west Pacific Ocean. International Journal of Remote Sensing 31(17-18): 4515-4530.
Xian, T., Sun, L., Yang, Y. \& Fu, Y. 2012. Monsoon and eddy forcing of Chlorophyll- $a$ variation in the northeast South China Sea. International Journal of Remote Sensing 33(23): 7431-7443.

Yee, T.W. \& Mitchell, N.D. 1991. Generalized additive models in plant ecology. Journal of Vegetation Science 2: 587-602.

Yu, W., Chen, X., Yi, Q., Chen, Y. \& Zhang, Y. 2015. Variability of suitable habitat of western winter-spring cohort for neon flying squid in the northwest pacific under anomalous environments. PLOS ONE 10(4): e0122997.

Zainuddin, M., Saitoh, K. \& Saitoh, S. 2004. Detection of potential fishing ground for albacore tuna using synoptic measurements of ocean color and thermal remote sensing in the Northwestern North Pacific. Geophysical Research Letters 31: L20311.

Zainuddin, M., Kiyofuji, H., Saitoh, K. \& Saitoh, S. 2006. Using multi-sensor satellite remote sensing and catch data to detect ocean hot spots for albacore (Thunnus alalunga) in the Northwestern North Pacific. Deep Sea Research Part II: Topical Studies in Oceanography 53(3-4): 419-431.

Zainuddin, M., Saitoh, K. \& Saitoh, S. 2008. Albacore (Thunnus alalunga) fishing ground in relation to oceanographic conditions in the western North Pacific Ocean using remotely sensed satellite data. Fisheries Oceanography 17: 61-73.

Zainuddin, M. 2011. Skipjack Tuna in relation to sea surface temperature and Chlorophyll- $a$ concentration of Bone Bay using remotely sensed satellite data. Jurnal Ilmu dan Teknologi Kelautan Tropis 3(1): 82-90.

School of Environmental Science and Natural Resources Faculty of Science and Technology

Universiti Kebangsaan Malaysia

43600 UKM Bangi, Selangor Darul Ehsan Malaysia

*Corresponding author; email: muzz@ukm.edu.my

Received: 14 September 2017

Accepted: 3 March 2018 